\title{
Dunarobba - den fossile skov
}

\section{Af geolog Nick Svendsen}

Italien er et dejligt ferieland. Der er meget at se på også for en geolog. Det følgende forslag til en spændende udflugt er ikke så spektakulært som vulkanerne Vesuv og Etna, men nok et besøg værd.

Umbrien ligger nordvest for Rom i Appenniner-bjergene og omkring Tiber-flodens dal. I den sydlige del af Umbrien, ved landsbyen Dunarobba, i 400 m's højde findes en lokalitet med resterne af en fossil skov bestående af Seqoia-træer.

\section{Fundet}

Lokaliteten ligger $8 \mathrm{~km}$ vest for autostradaen E45 (afkørsel Acquasparta) ved et større teglværk, hvor der graves fed ler med et højt indhold af bentonit. Det var i forbindelse med disse udgravninger, at man i 1980'erne fandt ca. 50 stubbe af arten Taxodioxylon gypsaceum, der ikke længere findes, men som er sammenlignelig med den recente art Sequoia sempervirens, der gror i Yellowstone Park i USA, og som kan blive op mod 1.000 år gammel.

\section{Stubbene}

De enkelte stubbe varierer i størrelse fra 1 til $8 \mathrm{~m}$ 's meters højde og 1,5 $\mathrm{m}$ i diameter. Træerne menes at være op mod 1,5 mil-
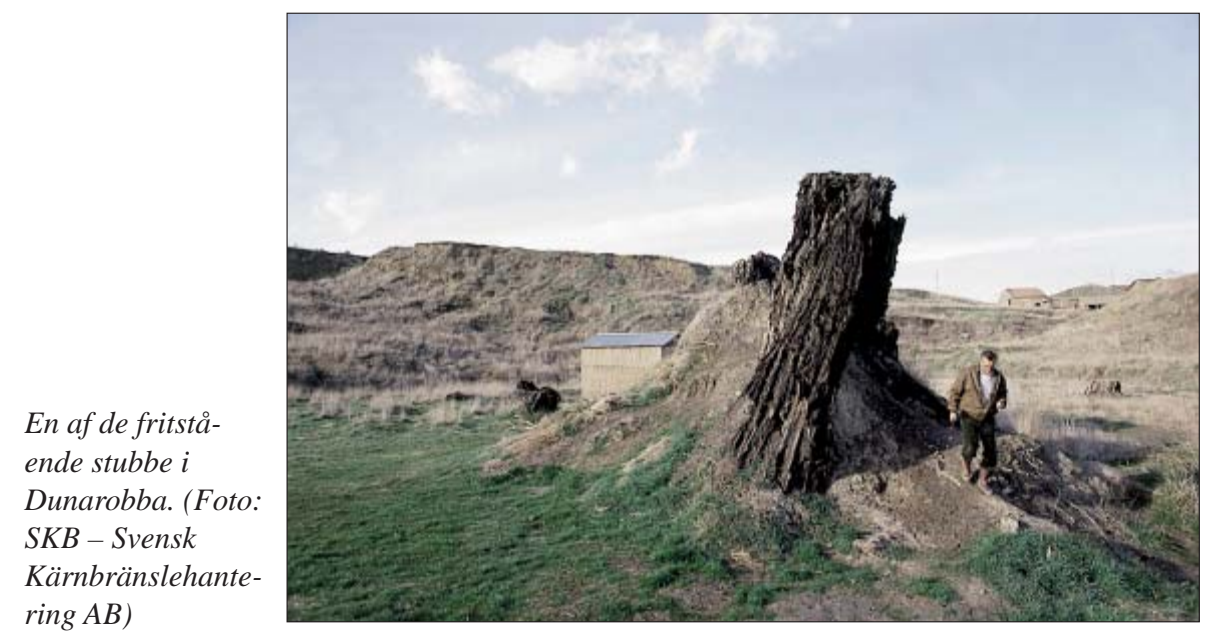

lioner år gamle. Da man fandt dem, var de indkapslet i det fede ler, hvilket må forklare, at træet stadig var bevaret uden at rådne. Oprindeligt stod træstubbene ubeskyttet, efter de var gravet ud. I dag er de blevet overdækket, hvilket ikke ser så kønt ud, men formodentlig en nødvendig foranstaltning for at bevare dem.

Leret er aflejret i en sø, der eksisterede efter, at området for 2 millioner år siden blev hævet over havniveau. Søen kaldes Tiberino.

\section{Appenninerne}

Appenninerne består af en hel serie af over-

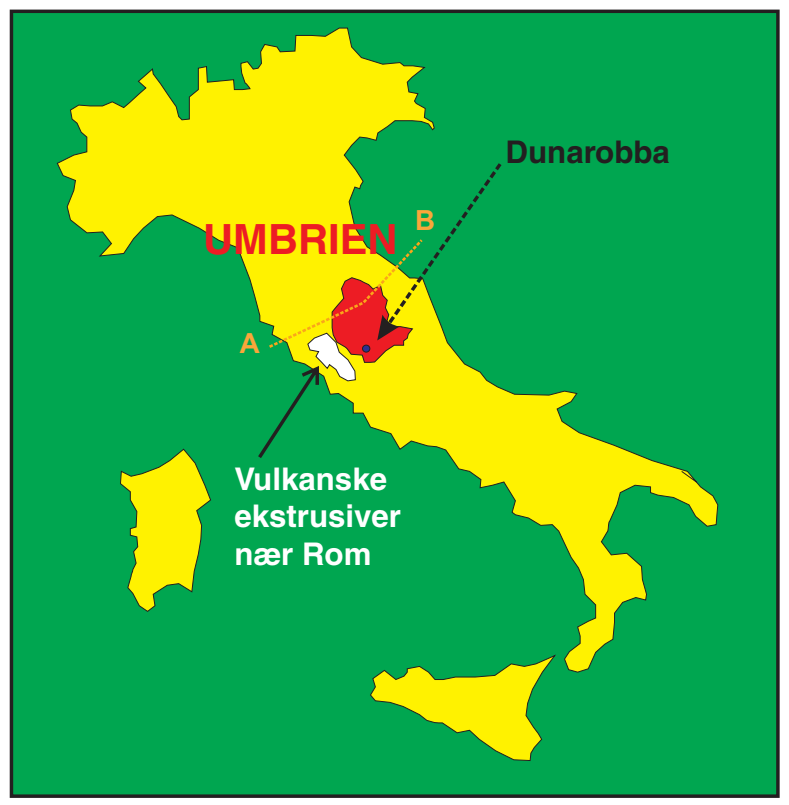

Dunarobbas beliggenhed $i$ Italien. (Grafik: Forfatteren) skydninger af de mesozoiske og tertiære sedimenter. Sedimenterne blev aflejret $i$ havet $i$ et fordyb indtil sent $i$ Tertiær. Herefter blev de foldet og skudt op over hinanden i et kompliceret mønster. I Pliocæn var det meste af den italienske halvø hævet over havniveau. Imellem de forskellige overskydninger dannedes nogle mindre bassiner, hvori der aflejredes lavtvandsmarine aflejringer eller lacustrine aflejringer. Tiberino-søen er et sådant bassin.

Ved overgangen mellem Tertiær og Kvartær begyndte den vulkanisme, som stadig er aktiv ved Vesuv og Etna. I området nær Rom findes også rester af vulkaner og vulkanske bjergarter såsom tuf. Den vulkanske aske, som disse vulkaner udspyede, skyllede ud i de lokale bassiner og findes $i$ dag som bentonit. På bredden af Tiberinobassinet voksede skove af typen som de ovenfor omtalte Taxodioxylon gypsaceum. Da træerne døde, blev stubbene indlejret $\mathrm{i}$

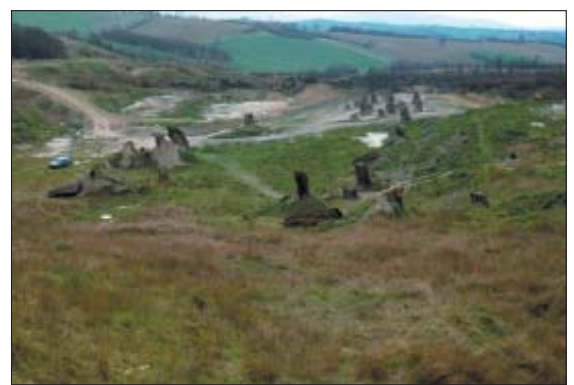

Dunarobba som der så ud, efter at stubbene var blevet udgravet. (Foto: Centro di Paleontologia i Dunarobba) 


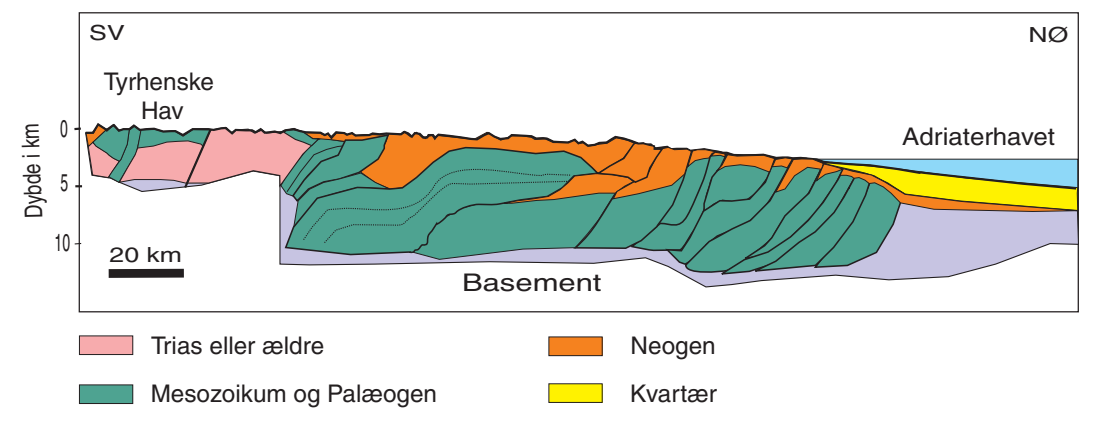

Tværsnit, der viser Appenninernes opbygning. (Grafik: Forfatteren modificeret efter Petroconsultaqnts s.a.)

det ler, der aflejredes i søen. Området blev hævet yderligere, og den barriere, som var årsag til søens dannelse, blev eroderet væk. Tiberino-leret ligger nu på kanten af en erosionsdal, der er en del af Tiber-flodens dræningssystem.

\section{Om lokaliteten}

Der findes et besøgs- og studie/dokumen- tationscenter ved lokaliteten, som man skal henvende sig til for at se træerne. De findes ca. 5 minutters gang fra landevejen.

Lokaliteten er et besøg værd, skulle man være på de kanter. Centeret har en hjemmeside med adressen:

\section{www.forestafossile.it}

Men husk, at alle museer er lukkede om mandagen, også i Italien.

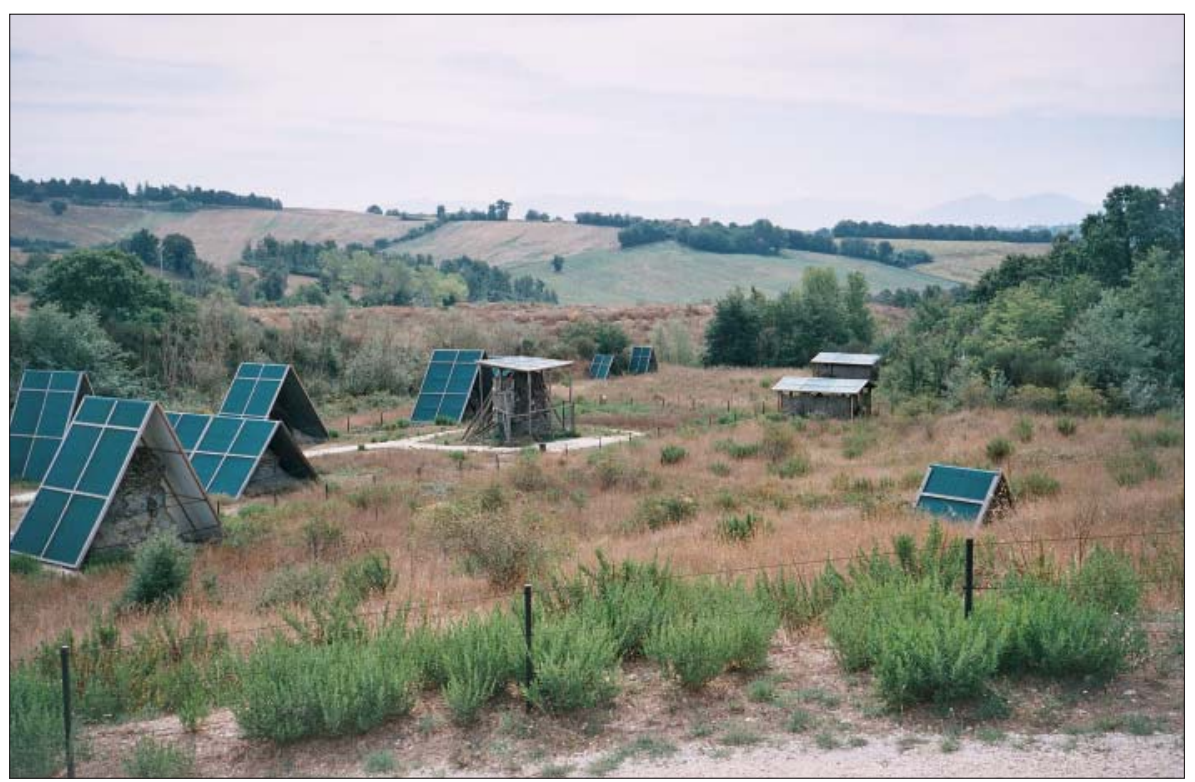

Dunarobba som der ser ud i dag. Træeerne er beskyttet, hvilket er nødvendigt, når man tager $i$ betragtning, at de er omtrent 1,5 millioner år gamle (Foto: Forfatteren)

\section{Kort nyt}

\section{Nyopdaget fisk lever i syreholdigt vand} En yderst hårdfør fiskeart, der netop er opdaget, klarer sig tilsyneladende under ekstreme forhold nær undersøiske vulkaner, hvor vandtemperaturen kan nå op på 180 grader, og hvor vandet er fyldt med tungmetaller.

Fiskene er observeret i havet nær Marianerne i det vestlige Stillehav, hvor de svømmer rundt i flydende svovl, som er akkumuleret i små søer i lavtliggende områder på havbunden - på meget dybt vand. Det varme vand kan være ekstremt syreholdigt - pH-værdien kan ligge helt nede på 2 som i svovlsyre. Projektet er finansieret af USA's nationale oceaniske og atmosfæriske administration, NOAA.

nyhederne.tv2.dk/UVH 